\title{
The 2008 eruption of the Chaitén Volcano, Chile: a preliminary report
}

\author{
Luis E. Lara
}

Servicio Nacional de Geología y Minería, Chile, Avda. Santa María 0104, Providencia, Santiago, Chile. lelara@sernageomin.cl

\begin{abstract}
On May 2, 2008 a Plinian eruption began on Chaitén volcano. Dome growing stage would have started on May 10-12 and extensive lahars and floods affected Chaitén town (ca. 5,000 inhabitants) on May 12. A volume up to $c a .4 \mathrm{~km}^{3}$ (non DRE) of rhyolitic magma would be extruded mostly during the explosive phase. Eruptive activity has not completely finished by the end of November. Because of the wide impact of this type of volcanism, this eruption poses a series of questions regarding explosive volcanism that should be addressed in the near future.
\end{abstract}

Keywords: Chaitén volcano, Plinian eruption, Chile, Southern Andes.

RESUMEN. La erupción 2008 del volcán Chaitén, Chile: informe preliminar. El 2 de mayo se inició una erupción pliniana en el volcán Chaitén. Entre el 10 y el 12 de mayo, se habría iniciado la construcción de un domo y el día 12 de mayo lahares e inundaciones afectaron la ciudad de Chaitén ( $c a .5 .000$ habitantes). Aproximadamente hasta $4 \mathrm{~km}^{3} \mathrm{de}$ magma riolítico (no ERD) habría sido evacuado principalmente durante la fase explosiva. Hacia fines de noviembre, la actividad eruptiva no había terminado por completo. Esta erupción plantea una serie de interrogantes científicas que deberían ser enfrentadas en un futuro cercano dado el amplio impacto que este tipo de volcanismo representa.

Palabras clave: Volcán Chaitén, Erupción pliniana, Chile, Andes del Sur.

\section{Introduction}

On May 2, 2008 a large volcanic eruption began in the southern Andes without significant precursory activity and, due to some conspicuous features (rhyolitic nature of the magma; long duration of the explosive phase, e.g., Sparks et al., 1997; extensive impact with $\sim 5000$ people evacuated), captured the interest of the scientific community (Fig. 1). This was also the first rhyolitic eruption to be recorded by geophysical tools (seismology, remote sensing) despite the isolation of the place where it happened. The more than 9 month long eruptive 2008 episode -not yet finished by late November- has posed several challenges for the scientific understanding of the event, short-term forecast capacity and crisis management. This article is intended as a brief, non exhaustive overview of the entire volcanic cycle based on the contributions of many people who worked hard to get the most relevant data in near real-time. Extensive overview and scientific articles should be written in the near future, when eruptive activity declines completely. The first account for scientific aspects is due to Carn et al. (2008) and several contributions would be presented to the 2008 AGU Fall Meeting. Technical reports on the ongoing eruption were timely uploaded at the SERNAGEOMIN institutional web page (www. sernageomin.cl). 


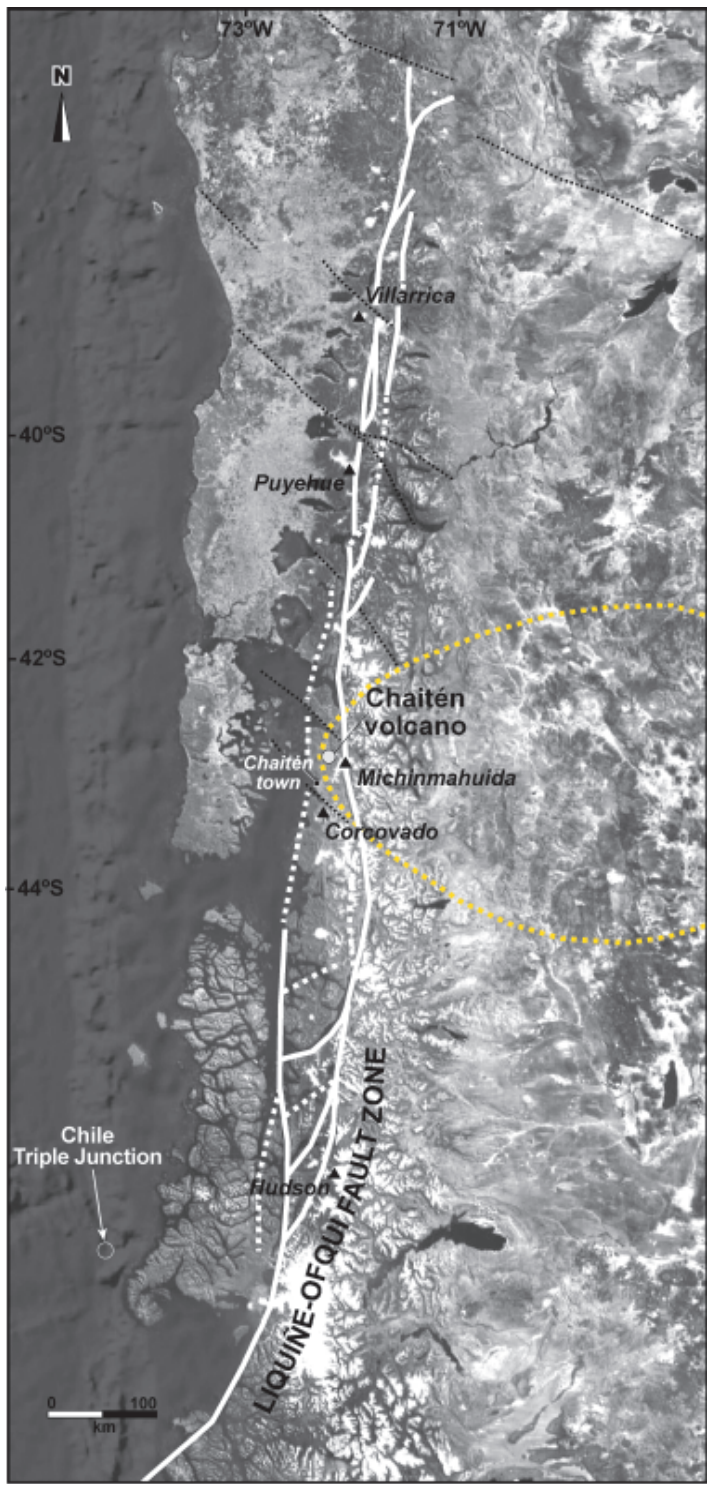

FIG. 1. Location map of Chaitén volcano. Main structural systems and some volcanoes are also shown. The dotted line roughly shows the limit of the 2008 ashfall deposit.

\section{Geology and eruptive history of Chaitén volcano}

The small Chaitén volcano $\left(42.83^{\circ} \mathrm{S}, 72.65^{\circ} \mathrm{W}\right.$, alt. $1,122 \mathrm{~m}$ ) is located in the southern Andes and its background geology is poorly known apart from the reconnaissance work done by Moreno (1995) and based on a study of aerial photographs. The last known major eruption occurred at ca. $9.4 \mathrm{ka}$ BP (Naranjo and Stern, 2004) and would have produced a small caldera ( $\sim 3 \mathrm{~km}$ diameter) accompanied by ejection of pyroclastic flows and ash fall deposits containing rhyolite pumice $\left(74 \mathrm{wt} \% \mathrm{SiO}_{2}\right)$. After the caldera collapse event, a large $\left(\sim 0.4 \mathrm{~km}^{3}\right)$ obsidian lava dome was built inside. No recent activity has been reported although growing evidence points to historical episodes. Prior to the 2008 eruption there were no evident signals of volcano unrest. Chaitén volcano is one among more than 120 active volcanoes of continental Chile but its threat was not considered at a high priority level, mostly by the lack of reported recent eruptions (Lara et al., 2006) and consequently it remained unmonitored until the beginning of the eruption.

\section{Chronology of the 2008 eruption and erupti- ve products}

Only 36 hours of precursory seismic activity were detected by distant instruments, located more than $300 \mathrm{~km}$ away from the Chaitén volcano. On April 30, some large volcano-tectonic (VT) earthquakes with coda magnitude up to 5 were located up to $20 \mathrm{~km}$ from Chaitén volcano. The number of large VT events reached up to 20 per hour on May 2 , coinciding with an initial Plinian eruption which began approximately at 8:00 UT (04:00 local hour) and lasted $c a .6$ hours with an eruptive column that rose up to $21 \mathrm{~km}$ as reported by eyewitness (Fig. 2). Seismicity declined abruptly by May 3, but sustained emission of ash plumes continued until May 6 when a second Plinian column reached $20 \mathrm{~km}$ in altitude (12:32 UT) and again on May 8 (03:36 UT). Despite the reported maximum column height (which is minor when constrained by satellite data, e.g., Carn et al., 2008), these Plinian eruptions produced only minor column-collapse pyroclastic flows restricted to local areas within the caldera and notably to the northern flank of the volcano. Ash columns were fed by several craters formed on the preexisting obsidian dome, mostly on its northern flank. Probably on May 10-12, extrusion of a new dome began although this was not confirmed until May 21 . Dome growing at high rates $\left(>20 \mathrm{~m}^{3} / \mathrm{s}\right)$ continued through late October, accompanied by lower ash columns $(<3.5 \mathrm{~km}$ altitude $)$ and steam emissions. For comparison, Soufrière Hills dome grew at $c a$.

\footnotetext{
1 Moreno, H. 1995. Estudio fotogeológico escala 1:100.000 de los volcanes de la X Región Sur. Proyecto Carta Metalogénica de la X Región Sur, Servicio Nacional de Geología y Minería (unpublished).
} 

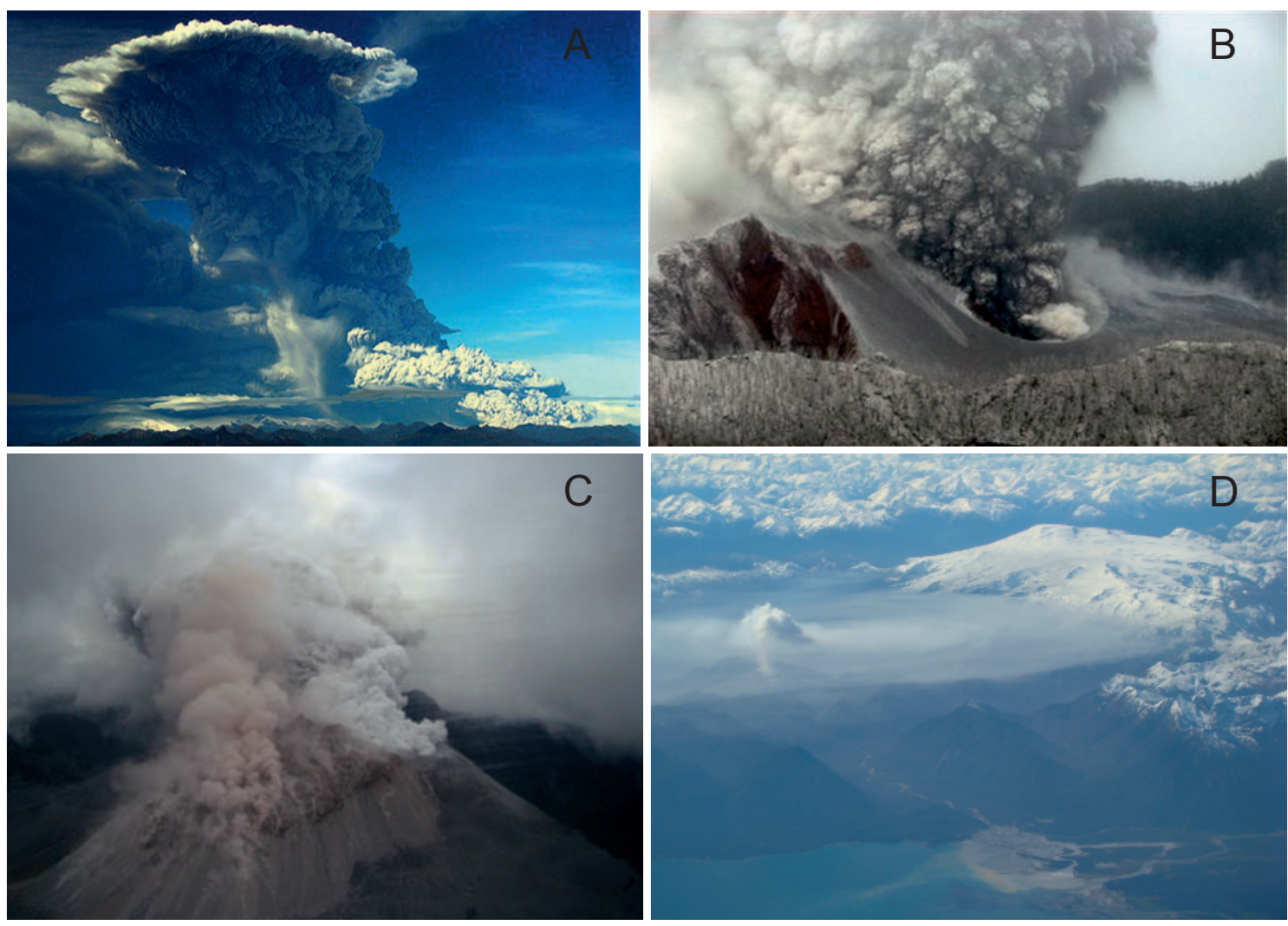

FIG. 2. Four stages of Chaitén 2008 eruption. A. Plinian column on May 2 (courtesy of http://www.throughthetube.com/) taken from Argentina; B. Active craters during the Plinian stage on May 6, now partially concentrated on the northern flank of the older dome (photo by Daniel Basualto); C. New dome (reddish) recognized on May 21 on the northern flank extruded over remnants of the ancient one (photo by L.E. Lara); D. Aerial view of a reduced although still active ash column on September 4 (photo by L.E .Lara).

$6 \mathrm{~m}^{3} / \mathrm{s}$ during 1979 and 1986 cycles (Huppert et al., 1982) and Mount Saint Helens did it at $c a .10 \mathrm{~m}^{3} / \mathrm{s}$ in 1980 (Murase et al., 1985). Dome extrusion has been accompanied by weak but sustained seismicity with a new swarm of VT earthquakes that began in late June and continued through July. Random increments of ash emissions occurred on July and August but as part of a long-term falling trend (Fig. $3)$. By September, seismicity declined and ash columns were no higher than $2 \mathrm{~km}$.

If maximum reported heights are taken into account, from empirical power law models that relates height of eruptive columns and discharge rates (e.g., Sparks et al., 1997), the cumulated volume during the Plinian phase (2-8 May) would have reached up to $c a .4 \mathrm{~km}^{3}$ of magma (non DRE), but it would not be higher than $1 \mathrm{~km}^{3}$ if duration of Plinian columns is considered (Carn et al., 2008). Volume estimates from ash thicknesses recorded at distal areas prior to erosion (80-150 km away from the source) yield values of about $4 \mathrm{~km}^{3}$ as well. Volcanic Explosivity Index (Newhall and Self, 1982) was estimated in the range of VEI 4-5.

Chaitén ashfalls revealed a very fragmented magma with up to $\sim 12 \%$ vol of respirable $(<4 \mu \mathrm{m})$ fine particles (Horwell et al., 2008) ${ }^{2}$ which becomes a respiratory health risk. Ash, pumice and obsidian samples of the 2008 eruption indicate a crystalpoor rhyolitic magma $\left(74-76 \% \mathrm{SiO}_{2}\right)$, similar to the previous dome and related pyroclastic deposits. No compositional changes were observed from the early Plinian phase to the present dome growing

\footnotetext{
2 Horwell, C.; Michnowicz, S.; Le Blond, J. 2008. Report on the mineralogical and geochemical characterisation of Chaitén ash for the assessment of respiratory health hazard. University of Durham-IVHHN-Natural Environmental Research Council (unpublished): 36 p.
} 


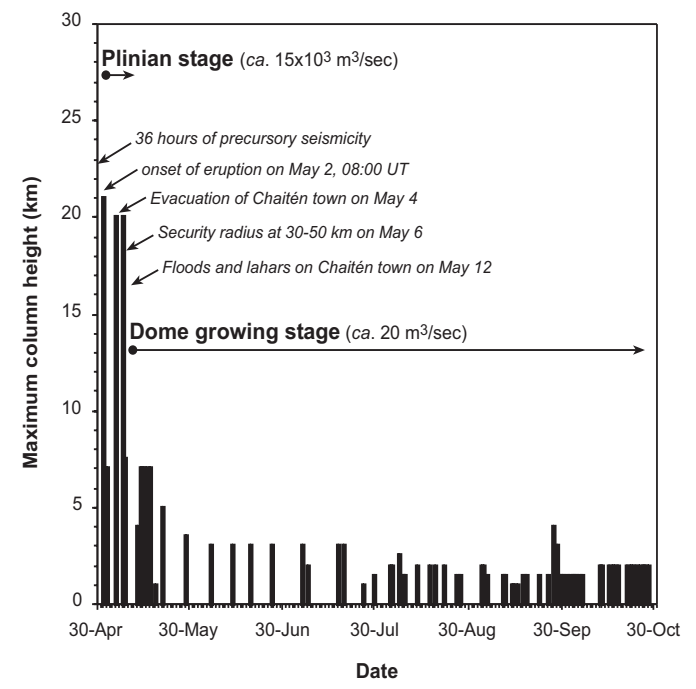

FIG 3. Trend of maximum column height (as reported by eyewitness). Some major facts are indicated in a time framework.

stage. Very low $\mathrm{SO}_{2}$ emissions were measured on the eruptive plume by remote sensing (Carn et al., 2008).

\section{Eruption response and impacts}

On May 4, SERNAGEOMIN (the Chilean Geological Survey) installed a seismic network around Chaitén volcano. In late May, real-time telemetered broadband seismometers were added with assistance from the U.S. Geological Survey (USGS) Volcano Disaster Assistance Program (VDAP). Parallel tracking of ash emissions was done by the Buenos Aires Volcanic Ash Advisory Center (VAAC) and the Universidad de Chile using satellite data. NASA's satellite constellation also provided direct measurement of volcanic clouds (ozone, $\mathrm{SiO}_{2}$, ash mass loading).

Crisis assessment was carried out by SERNAGEOMIN in close relation with both regional and national authorities. Active media releases kept national and international communities informed. Preventive evacuation of $c a$. 5,000 residents was ordered on May 4-5 and two security radius were defined at 30 and $50 \mathrm{~km}$ on May 6 based on scientific advice. This was done 6 days before the Chaitén city was affected by floods on May 12. A volcanic hazards map was done during the crisis to advice emergency management (Moreno and Lara, 2008) ${ }^{3}$.

Impacts of the eruption were extensive in Chile and Argentina. Floods and lahars inundated the already evacuated Chaitén town on May 12 and up to US $\$ 12$ millions are the estimated economic losses only by insured public buildings. Ash clouds shut down regional airports and forced the cancellation of hundreds of domestic flights and several international flights in Argentina and Chile. Floods also disrupted the backbone road of continental Chile and the active aquiculture industry was severely affected (Fig. 4). More than US\$36 millions have been allocated for the social support to evacuated people.

\section{Challenging scientific aspects}

Plinian eruptions are scarce and occur at a rate of a few per century around the world. Rhyolite magmas are scarcer than basalt-andesite suites and the driving processes for rhyolitic eruptions are an important field of research. The large quiescence period before the eruption without any unrest signals is also remarkable. On the other hand, most historic Plinian eruptions ended no later than 36 hours after the paroxysmal stage (e.g., Sparks et al., 1997). The long duration of the explosive phase with repeated Plinian columns and sustained explosions that still accompany the dome growing is uncommon. The very short period of seismic activity before the onset of the eruptive activity is also intriguing. Extremely low $\mathrm{SO}_{2}$ emissions measured in the eruption clouds, lower than expected even for rhyolitic magmas, still require explanation. Finally, a better knowledge of long-term evolution of Chaitén volcano and basic geology is urgently needed.

\section{Acknowledgements}

I thank M. Suárez, Chief Editor of Andean Geology, the invitation to prepare a note on the Chaitén eruption. H. Moreno, D. Basualto, P. Peña, C. Delgado and C. Gallegos, the staff of the OVDAS (Observatorio Volcanológico de los Andes del Sur) from SERNAGEOMIN were part of the task force that worked hard on the crisis and much of the trend analysis is based on their reports. J. Muñoz was responsible for coordination and support in the area and maintained a close relationship with the local authorities. R. White, A. Lockhart, J. Marso and J. Power from VDAP-USGS assisted with the monitoring network and data retrieval and analysis. J. Pallister and J. Ewert from VDAP-VHP(USGS) also contributed with

3 Moreno, H.; Lara, L.E. 2008. Peligros volcánicos potenciales del volcán Chaitén (erupción de mayo 2008), Región de los Lagos. Servicio Nacional de Geología y Minería, 1 mapa escala 1:500.000 (unpublished). 

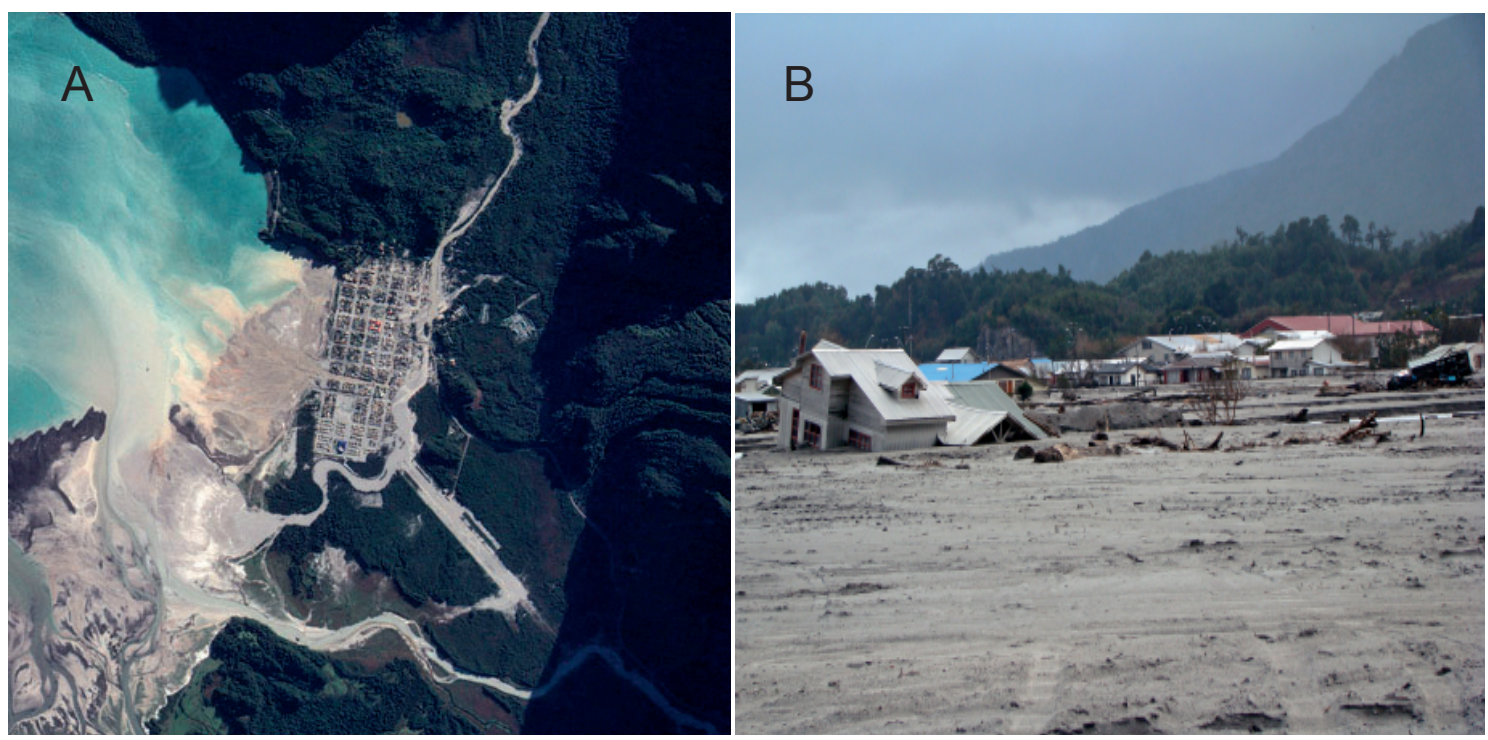

FIG 4. Extensive damage in Chaitén town generated by floods and lahars. A. Satellite image acquired on May 19 shows both the inundated area and the suspended sediment due to the coastal drift (courtesy of NASA at http://earthobservatory.nasa.gov); B. Severe damages on the urban infrastructure (photo by L.E. Lara).

many ideas about the ongoing volcanic crisis. R. Aguilera (Universidad de Chile) and A. Pavez shared satellite images and tracked the ash dispersion. R. Wall and W. Vivallo supervised the eruption response as executive officers of SERNAGEOMIN. G. Villarrosa (Universidad Nacional del Comahue) shared valuable data of ash thickness in Argentina before the extensive erosion. Students of GL611 at the Universidad de Chile were involved in volume estimations as part of their basic training. J. Caballero and M. Soto (SERNAGEOMIN) managed the media releases putting in simple words the technical reports. Valuable field assistance was provided by Carabineros de Chile (especially J. López and A. Villablanca) and Armada de Chile and many thanks go to them. Without the support from all of these people this contribution would not have been possible. This modest work is dedicated to Chaitén's residents, whose lives were severely disrupted by the eruption.

\section{References}

Carn, S.A.; Pallister, J.S.; Lara, L.E.; Ewert, J.; Fromm, M.; Watt, S.; Prata, A.J.; Thomas, R. In press. The awakening of Chaitén volcano, Chile. EOS.

Manuscript received: October 01, 2008; accepted: November 06, 2008.
Huppert, H.E.; Shepherd, J.B.; Sigurdsson, H.; Sparks, R.S.J. 1982. On lava dome growth, with application to the 1979 lava extrusion of the Soufrière of St. Vincent. Journal of Volcanology and Geothermal Research 14: 199-222.

Lara, L.E.; Clavero, J.; Hinojosa, M.; Huerta, S.; Wall, R.; Moreno, H. 2006. NVEWS-CHILE: Sistema de Clasificación semicuantitativa de la vulnerabilidad volcánica. In Congreso Geológico Chileno, No. 11, Actas 2: 487-490. Antofagasta.

Murase, T.; McBirney, A.; William, G.M. 1985. Viscosity of the dome of Mt. St. Helens. Journal of Volcanology and Geothermal Research 24: 193-204.

Naranjo, J.A.; Stern, Ch. 2004. Holocene tephrochronology of the southernmost part $\left(42^{\circ} 30^{\prime}-45^{\circ} \mathrm{S}\right)$ of the Andean Southern Volcanic Zone. Revista Geológica de Chile 31 (2): 225-240.

Newhall, C.G.; Self, S. 1982. The volcanic explosivity index (VEI): An estimate of explosive magnitude for historical volcanism. Journal of Geophysical Research 87: 1231-1238.

Sparks, R.S.J.; Bursik, M.I.; Carey, S.N.; Gilbert, J.S.; Glaze, L.S.; Siggurdsson, H.; Woods, A.W. 1997. Volcanic Plumes. John Wiley and Sons: 574 p. New York. 